\title{
Sfântul Grigorie Palama şi cântarea liturgică. Câteva repere
}

\section{Roger CORESCIUC *}

\begin{abstract}
St. Gregory Palamas and the liturgical song. Some remarks. The homilies of St. Gregory Palamas are not only dogmatic or moral sermons, but they also contain some references to liturgical singing. These references are not very numerous, but, together with some elements from the biography written by the patriarch Filotei, they can help us to draw an adequate image of the way in which the church music was valued in the XIV-th century. The role of this study is also to show that church music was not neglected during the time of St. Gregory Palamas, but was given due importance. Along with these elements, the present study will also highlight the importance that St.

Gregory Palamas attaches to the connection between church singing and the prayer of the mind, which is a central element of hesychastic life. Attention in prayer is not only a feature of particular prayer, but it must also be present in liturgical singing. Hesychia and liturgical prayer are not two antagonistic forms of prayer, they are not two independent forms of prayer, but they complement each other, with the main purpose of an assumed prayer. If the liturgical prayer is not prepared by personal prayer, it risks becoming a simple ritual, without authentic spiritual implications. The homilies of Saint Gregory Palamas also show us that the church hymns had as subjects the divine mysteries of the Incarnation, the life of the Mother of God and the lives of the saints.
\end{abstract}

Keywords: Palama, psalmody, hesychasm, mindfulness, homelies.

Evocarea marii personalităţi a sfântului Grigorie Palama nu se poate face fără o referire şi la felul în care acesta era ataşat de viaţa liturgică a Bisericii. Literatura teologică cu privire la disputele isihaste este imensă, însă credem că această literatură, centrată

\footnotetext{
* Lector universitar la Facultatea de Teologie Ortodoxă „Dumitru Stăniloae” din Iaşi, Universitatea „Alexandru Ioan Cuza”, Romania.
} 
destul de mult pe chestiunile dogmatice ale disputei, trebuie să cuprindă şi o imagine a dinamicii participării sfântului la filonul liturgic tradiţional. De asemenea, chestiunea muzicală nu ocupă un loc special în teologia sfântului Grigorie, poate şi pentru că făcea parte din firescul liturgic de zi cu zi şi nu impunea o abordare particulară. $\mathrm{Nu}$ sunt multe textele în care sfântul vorbeşte despre cântare, iar în studiul de faţă ne vom opri doar asupra câtorva pasaje din „Omilii” şi din biografia pe care i-a alcătuit-o Filotei, patriarhul Constantinopolului.

\section{Elemente din biografia Sfântului Grigorie Palama cu referire la cântarea liturgică}

Aceste elemente nu sunt foarte numeroase şi sunt cuprinse în general în biografia pe care i-a dedicat-o Filotei. Firescul liturgic, care făcea parte integrantă din viaţa monahului athonit, nu a constituit o preocupare descriptivă nici pentru Filotei şi nici pentru Sfântul Grigorie. Redăm mai jos câteva astfel de elemente, cu comentariile de rigoare.

Unul dintre momentele de criză care prezintă felul în care sfântul Grigorie se raporta la cântarea de la strană este cuprins în rândurile următoare:

„Era seara Cinei celei mari şi de taină şi a Pătimirilor după trup ale Domnului, şi săvârşindu-se cu măreţie celebrarea lor, cum e obiceiul în Lavră, Grigorie participa împreună cu cei mai de vază la prăznuire şi imne, conducând şi stând împreună cu ceilalţi şi împodobind adunarea cu prezenţa lui, cum ar putea spune cineva. Dar cum obişnuieşte să se întâmple, unii dintre cei ce stăteau acolo, ca şi cum ar fi uitat de cele celebrate, de acele mari şi minunate cântări şi pentru ce se adunaseră, s-au dedat vorbelor întâmplătoare, şi aceasta peste măsură şi în exces, dacă s-ar putea vorbi despre măsură în unele ca acestea. La acestea omul lui Dumnezeu s-a mâhnit, cum era şi potrivit, şi pentru că nu i se părea indicat să vorbească cu ei să le spună să se abţină de la vorbe, îndepărtându-şi mintea deodată de la aceia şi de la cântarea imnelor, s-a întors ca de obicei spre sine 
însuşi şi prin sine spre Dumnezeu. Şi dintr-odată l-a învăluit de sus o lumină dumnezeiască şi, luminând-i-se cu razele acelea atât ochii sufletului, cât şi ai trupului, a văzut deja limpede ca prezent ceea ce avea să se întâmple peste nu puţini ani”’.

Traducătorul biografiei lui Teolipt precizează într-o notă aferentă acestui text că această întâmplare a avut loc în anul $1332^{2}$. Sfântul Grigorie a fost hirotonit preot în 1326. Textul de mai sus ne lasă să înţelegem că la această priveghere, Palama nu doar a slujit, ci a şi participat la cântarea de la strană. Mâhnirea produsă de vorbăria unora dintre monahi (despre care nu putem afirma categoric, dar nici exclude, că erau înşişi psalţii) 1-a îndepărtat de cântare şi 1-a orientat către rugăciunea inimii. Întoarcerea spre sine şi ferirea de împrăştierea prin cuvânt 1-au ajutat pe sfânt să se întoarcă în mod real către Dumnezeu într-o situaţie aparent nefavorabilă, fapt care a condus şi la vederea profetică a unor realităţi care aveau să se întâmple peste o anumită perioadă de timp (alegerea ca mitropolit al Tesalonicului a lui Macarie în 1343). Episodul acesta reflectă felul de vieţuire isihastă care nu permite gândurilor sau vorbelor deşarte să abată mintea de la rugăciune. Unul dintre primii dascăli ai Sfântului Grigorie, Teolipt al Filadelfiei, spune exact acelaşi lucru (fapt care ne îndreptăţeşte o dată în plus să ţinem cont de relaţia de paternitate Teolipt-Palama atunci când dorim să înţelegem mediul în care s-a dezvoltat duhovniceşte sfântul Grigorie): „Dar vreau să ştii şi aceasta: $\mathrm{Nu}$ cumva, socotind că te rogi, să umbli departe de rugăciune, să te osteneşti fără câştig şi să alergi în deşert. Aceasta se întâmplă la cântarea cu gura, când mintea e purtată în altă parte şi e împărţită între patimi şi lucruri încât se întinează şi înţelesul cântării"3. $\mathrm{Cu}$

${ }^{1}$ FiLOTEI, preasfântul patriarh al Constantinopolului, Cuvânt la cel intru sfinţi Părintele nostru Grigorie, arhiepiscopul Tesalonicului, în GRIGORIE PALAMA, Tomosuri dogmatice. Viaţa. Slujba. Scrieri I, trad. Ioan I. Ică jr., Sibiu, Edit. Deisis, 2009, p. 501-502.

${ }^{2}$ Ibidem. A se vedea nota 31 , p. 502.

${ }^{3}$ Teolipt al FiladelfieI, Despre ostenelile vieţii călugăreşti, în Filocalia sfintelor nevoinţe ale desăvârşirii, vol. VII, trad. Dumitru Stăniloae, Bucureşti, Edit. Humanitas, 1999, p. 56. 
toate acestea, după cum vom vedea în continuare, sfântul Grigorie acordă cântării importanţa cuvenită. În întâmplarea de faţă, Palama nu amendează cântarea în sine, ci atitudinea neglijentă a celor care cântă. Acelaşi Teolipt avea, probabil, să îl înveţe pe sfântul Grigorie: „Psalmodiază cu gura. Dar cu glas liniştit şi cu supravegherea minţii, nerăbdând să laşi ceva necugetat [ne-gândit] din cele spuse. Şi dacă iți scapă ceva minţii, repetă stihul ori de câte ori se întâmplă aşa ceva, până-ţi vei avea mintea însoţind cele spuse. Căci mintea poate să şi cânte cu gura şi să ţină şi amintirea lui Dumnezeu"4.

De asemenea, deşi nu există dovezi clare ale unei relaţii directe între sfântul Grigorie Palama şi sfântul Grigorie Sinaitul, nu putem să ignorăm influenţa indirectă pe care cel din urmă a avut asupra primului, inclusiv în ceea ce priveşte atitudinea faţă de cântare. Reacţia lui Palama în contextul slujbei amintite mai sus poate fi explicată, probabil, şi prin ecoul pe care învăţătura despre cântare a sfântului Grigorie Sinaitul îl avea în inima lui Palama. Spune Grigorie Sinaitul:

„Unii cântă puţin, alţii mult, alţii deloc. Tu nu cânta nici mult, căci aceasta aduce tulburare, dar nici nu lepăda cu totul cântarea, pentru moleşeala şi nepăsarea care se nasc din aceasta [...]. Cântarea multă este a celor ce se îndeletnicesc cu făptuirea, pentru necunoştinţă şi pentru osteneală ; nu a celor care se liniştesc, cărora le ajunge să se roage numai lui Dumnezeu, în inimă, şi să se abţină de la gânduri [...]. Căci dacă îşi deşartă mintea toată puterea în cântare, slăbeşte de nu se mai poate ruga cu tărie şi cu sârguinţă"’

Echilibrul între cântare şi rugăciunea în isihie este important pentru felul în care monahul îşi rânduieşte lumea gândurilor. Sfântul Grigorie Palama reacţionează categoric când psalţii se îndepărtează de liniştirea minţii, urmând întrucâtva cuvintele lui

${ }^{4}$ Ibidem, p. 64.

5 Sfântul GRIGORIE SinAitul, Despre felul cum trebuie să şadă la rugăciune, în Filocalia sfintelor nevoinţe ale desăvârşirii, vol. VII, trad. Dumitru Stăniloae, Bucureşti, Edit. Humanitas, 1999, p. 191. 
Grigorie Sinaitul: „Când vezi, şezând în scaunul tău, că lucrează rugăciunea şi nu încetează de a se mişca în inimă, nu o părăsi ca să te scoli să cânţi, până ce nu te va părăsi ea cu bun rost, când vine vremea, căci părăsind pe Dumnezeu înăuntru pentru ca, ridicândute, să-i vorbeşti în afară, te cobori de la cele înalte la cele de jos. Ba iţi tulburi prin aceasta şi liniştea minţii"’6.

În acelaşi timp, episodul participării la cântarea de la priveghere este paradigmatic pentru înţelegerea felului în care sfântul, deşi pe deplin trăitor al rugăciunii isihaste, nu o absolutizează, acordând importanţă deosebită şi sinaxelor liturgice, într-un deplin echilibru. Facem această remarcă deoarece este cunoscut faptul că Sfântul Grigorie, cel puţin în perioada vieţuirii în Athos, a ales pentru o perioadă vieţuirea în retragere, fiind prezent în mănăstire doar în zilele de sâmbătă şi duminică: „Era de obicei într-o isihie extremă, singur cu el însuşi şi cu Dumnezeu, şi nici nu ieşea deloc din colibă, nici nu venea să vorbească şi să vadă pe absolut nimeni, întrucât nu suporta să-l vadă nici măcar pe cel care slujea nevoilor sale legate de strictul necesar, afară de sâmbăta şi duminica, în care putea fi văzut şi abordat şi de ceilalţi"”. Cu toate acestea, nu a ignorat viaţa liturgică, păstrând echilibrul necesar între isihie şi Liturghie.

Observăm, de asemenea, din textul lui Filotei, că săvârşirea deniei din Joia Mare se făcea „cu măreţie”, conform obiceiului din Marea Lavră. Cântările, conform lui Filotei, erau „mari şi minunate". Potrivit tradiţiei athonite, şi astăzi, la privegherile mari de noapte, sunt folosite cântările ,pe larg”. Sfântul Grigorie participa la aceste slujbe, care durau foarte mult, atât ca slujitor, cât şi ca psalt (,,conducând şi stând împreună cu ceilalţi şi împodobind adunarea cu prezenţa lui'). Această relatare din Joia Mare, în care vedem că sfântul Grigorie era implicat în cântarea de la strană, nu este însă singulară. Faptul că Sfântul Grigorie, în general, participa activ la cântare este confirmat de acelaşi Filotei şi în altă parte a

${ }^{6}$ Sfântul GRIGORIE Sinaitul, Despre felul cum trebuie să şadă la rugăciune, p. 191-192.

${ }^{7}$ FILOTEI, preasfântul patriarh al Constantinopolului, Cuvânt la cel intru sfinţi..., p. 493. 
„Vieţii”: „Căci poruncindu-i-se de către întâi-stătătorul Lavrei să poarte grijă de o parte a mesei comune a fraţilor, cum este obiceiul la ei, şi să stea împreună cu cei ce cântă în biserică şi să cânte împreună cu ei cântările dumnezeieşti, s-a arătat plin de toate acestea" 8 . În perioadele în care nu a trăit în singurătate, Sfântul Grigorie a fost şi psalt, asumându-şi ascultarea primită de la stareţul Marii Lavre. Echilibrul acesta între isihie şi sinaxele liturgice este foarte important, şi insistăm asupra acestui lucru pentru că în acest fel atragem atenţia că textele Sfântului Grigorie nu pot fi folosite pentru fundamentarea unei teologii non-ecleziologice. Isihia este, pentru Sfântul Grigorie, întru totul compatibilă cu liturghia şi cu toate formele de laudă liturgică. Ele nu sunt două realităţi contradictorii, ci o împletire cât se poate de firească a două stări complementare.

Atitudinea Sfântului Grigorie faţă de cântarea bisericească reiese şi din relatările aceluiaşi Filotei cu privire la scurta perioadă în care dascălul isihast a fost stareţ la Esfigmenu:

„Ce mai e nevoie să spunem de convorbirile şi învăţăturile lui continue şi variate, de acel râu de aur nestăvilit al cuvântului său, de sârguinţa şi iubirea de frumos a aceluia pentru lăcaşul dumnezeiesc, pentru slujitorii şi cântăreţii lui, de Liturghiile şi celebrările tainice ale Tainelor supranaturale şi sublime, încă şi despre buna podoabă din sfântul altar, de purtarea de grijă şi de înălţarea celor care celebrau ca preoţi slujbele şi pe care o insufla confraţilor săi şi numai fiind văzut celebrând în chip supranatural cele dumnezeieşti şi tainice?"’.

Din textul de faţă observăm grija Sfântului Grigorie pentru spaţiul liturgic. Din păcate, compromisul cu privire la spaţiul şi mediul liturgic reprezintă pentru omul contemporan o problemă importantă, care nu poate fi uşor sesizată în toate situaţiile. Inovaţia cultică şi muzicală, împrumuturile de tot felul din tradiţiile cultice

\footnotetext{
${ }^{8}$ Ibidem, p. 484.

${ }^{9}$ Ibidem, p. 506.
} 
apusene, renunţarea la tradiţia muzicală consacrată, accentul pus pe suscitarea emoţiei şi a sentimentalismului sunt doar câteva dintre aspectele care invadează viaţa muzicală-liturgică contemporană. Filotei afirmă clar ataşamentul lui Palama faţă de tradiţia cultică. Sfântul Grigorie s-a îngrijit ca stareţ la Esfigmenu de calitatea desăvârşită a spaţiului liturgic (,buna podoabă din sfântul altar ”), a dinamicii liturgice (purtarea de grijă faţă de modul slujirii) şi a cântării. Săvârşirea Liturghiei nu putea fi văduvită de această purtare de grijă şi suntem convinşi că Sfântul Grigorie însuşi era un exemplu în acest sens. Rânduiala slujbelor este întotdeauna însoţită de cântare şi Sfântul Grigorie acordă importanţa cuvenită şi acestui aspect ${ }^{10}$. Presupunem că ,iubirea de frumos" cu privire la cântare se va fi materializat în primul rând în rânduiala cântării, apoi, probabil, în asigurarea suporturilor fizice necesare cântării săvârşite în rânduială (colecţii de cântări etc.).

\section{Câteva pasaje din omiliile palamite cu privire la cântare}

Ca şi în cazul biografiei Sfântului Grigorie, nici în „Omiliile” sale nu întâlnim multe pasaje care să facă referire la cântare. Aşa cum am văzut, moştenirea lăsată de Teolipt şi Grigorie Sinaitul ne ajută să ne formăm o idee destul de clară despre felul în care era valorizată cântarea şi care erau limitele duhovniceşti ale implicării în cântarea de la strană. În „Omilii” întâlnim, aşadar, pasaje disparate cu privire la cântare.

${ }^{10}$ Este interesant faptul că în aceeaşi relatare biografică, Filotei aminteşte tocmai despre vindecarea, după moartea Sfântul Grigorie, a unui protopsalt din Tesalonic (p. 618-620). Înţelegem şi din detaliile acestei relatări în ce măsură muzica psaltică îşi avea rolul ei bine definit în dinamica liturgică. Filotei îl descrie pe acest protopsalt ,drept şef peste sfintele cântări şi melodii şi căpetenie şi corifeu al corului cântăreţilor, fiind renumit în acelea şi prin timp şi prin experienţă şi prin fire şi prin tehnică, precum şi prin toate cele ce contribuie la acestea” (p. 618). Această descriere ne ajută să înţelegem că atmosfera muzicală-liturgică a vremii, în care s-a dezvoltat şi sfântul Grigorie, acorda locul cuvenit cântării psaltice. 
Astfel, în „Omilia a III-a”, Sfântul Grigorie atrage atenţia asupra felului în care creştinul poate deveni o pradă uşoară atacurilor vrăjmaşului dacă nu rămâne ferm în atitudinea sa faţă de frecventarea bisericii. Această frecventare presupune o prezenţă activă a creştinului, care implică atât ascultarea de cuvântul preotului şi al ierarhului, cât şi asumarea conţinutului cântărilor de la slujbe: „Când însă [diavolul] îl desparte pe cineva de cântarea cea sfântă şi de ascultarea sfinţilor învăţători atunci îl îndepărtează şi de dumnezeiasca purtare de grijă, predându-1 pe acesta faptelor sale celor rele"11. Abandonarea prezenţei la slujbe înseamnă o ieşire din cadrul purtării de grijă a lui Dumnezeu şi o predare voluntară acţiunii patimilor. Această ieşire din atmosfera liturgică coincide cu o despărţire a minţii de Dumnezeu şi de făgaşul imprimat de întoarcerea spre sine. Mintea, fără liturghie şi fără cântarea aferentă, se risipeşte şi se revoltă împotriva ordinii fireşti a relaţiei omDumnezeu.

Ideea este oarecum reluată în „Omilia a VII-a”. Sfântul Grigorie atenţionează de data aceasta că abandonarea rugăciunii în particular reprezintă un pericol important pentru viaţa creştinului. Această abandonare sau neglijare a rugăciunii particulare are însă drept consecinţă şi incapacitatea unei asumări la potenţial maxim a rugăciunilor şi cântărilor din sinaxa liturgică. Cel care nu se îngrijeşte de rugăciunea de acasă se va prezenta nepregătit pentru slujba de la biserică. Rugăciunile sinaxei liturgice sunt întărite de sinaxa isihastă de acasă sau de la chilie:

„Ci, pe lângă altele mai înalte, pe care timpul nu ne îngăduie să le spunem acum, Domnul ne învaţă [şi] că deşteptarea la rugăciunea tainică făcută în casele sau în dormitoarele noastre întăreşte rugăciunea către Dumnezeu făcută în biserici, şi că rugăciunea lăuntrică [săvârşită] în minte, o întăreşte pe cea săvârşită cu buzele. Căci cel care vrea să se roage numai când vine în biserica lui Dumnezeu, dar nu se îngrijeşte deloc de rugăciune atunci când este acasă, sau pe

11 Sfântul Grigorie Palama, Omilii I, trad. Roger Coresciuc, Iaşi, Edit. Doxologia, 2019, p. 53. 
drumuri sau în pieţe, nu va putea să se roage cu adevărat nici atunci când se află în biserica lui Dumnezeu. Acestea le arată şi cel care, după ce spune: Gata este inima mea, Dumnezeule, adaugă: Îţi voi cânta [cu glasul] şi din strune întru slava mea [Ps. 107, 1]"12.

Relaţia cu Dumnezeu nu se reduce doar la spaţiul liturgic şi la cântarea aferentă acestui spaţiu. Sfântul Grigorie Palama precizează foarte clar că rugăciunea lăuntrică este esenţială pentru integrarea în dinamica rugăciunii liturgice. Această rugăciune lăuntrică ar trebui să fie una permanentă, neîncetată (,acasă, pe drumuri sau în piețe") şi nu una circumstanţială. Rolul cântării este acela de a valorifica în sinaxa liturgică tocmai această singularitate a rugăciunii lăuntrice. Cel care se adânceşte în rugăciune în viaţa privată, şi nu are ascultare de psalt, participă tăcut la cântarea Bisericii, asumând interior conţinutul cântărilor. Această legătură între rugăciunea lăuntrică şi rugăciunea-cântarea liturgică nu impune şi forme comunitare de cântare. Asumarea acestor cântări nu înseamnă dezvoltarea unor forme de ,gospel”, ci înseamnă tocmai forme de rugăciune lăuntrică însoţite de ascultarea cântărilor monodice de la strană. Pretenţia cântării în comun, atât de prezentă în zilele noastre, ar strica tocmai acest echilibru dintre lăuntric şi liturgic. Cel care vine la slujbele Bisericii şi este practicant al rugăciunii lăuntrice va prefera mereu să nu strice rânduiala cântării de la strană prin pretenţiile sale de a participa comunitar la cântare, dorindu-şi să râmână adâncit în sine şi prezent tăcut în cântarea liturgică, evitând riscul risipirii inutile. Trezvia necesară urmăririi atente a slujbelor şi cântărilor este descrisă şi de sfântul Simeon Noul Teolog într-una dintre „Catehezele” sale:

„[Monahul] trebuie să se scoale la miezul nopţii, înainte de utrenie şi să se roage cu rugăciunea rânduită, şi aşa după aceasta să stea în picioare împreună cu toţi la doxologie şi să o urmărească toată cu atenţie şi cu trezvie luând foarte mult aminte la începutul imnodiei, adică la cei şase psalmi, la

${ }^{12}$ Ibidem, p. 100. 
stihologie şi la citiri în chip nezăbavnic, nerelaxându-şi trupul şi sprijinindu-se de pe un picior pe altul, sau rezemându-se de ziduri sau de coloane [...] ; ci mai degrabă se cade să ia seama numai la psalmodie şi la citire, şi la înţelesul celor cântate şi a cuvintelor citite din dumnezeiasca Scriptură" $" 13$.

Sfântul Simeon precizează clar că înaintea venirii la slujbele Bisericii, monahul este dator să îşi împlinească pravila, tocmai pentru a se pune în starea rugăciunii făcute cu trezvie şi pentru a fi capabil să urmărească în mod adecvat cântările şi citirile de la strană.

În „Omilia a VI-a”, Sfântul Grigorie pune în paralel cântecele lumeşti, născute din diferite patimi, cu cântecele duhovniceşti, născute din viaţa curată. Prezentăm mai jos un fragment mai lung în care arhiepiscopul Tesalonicului face o radiografie complexă a perioadei de dinaintea Postului Mare:

„Căci în cele două săptămâni care au trecut, lăcomia la mâncare şi mai ales lipsa de cumpătare au pus stăpânire pe cetate, şi îndată [s-au pricinuit] tulburări, şi strigăte, şi încăierări, şi zarvă, şi cântece curveşti, şi dansuri satanice, şi râsete obscene. Dar săptămâna aceasta a venit postul şi pe toate le-a schimbat într-o stare mai de cinste, alungând grijile cele costisitoare ale deşertăciunii şi oprind truda pentru pântecele rămas fără lucrare. [Postul] ne-a schimbat, [îndreptându-ne] către faptele pocăinţei şi convingându-ne să muncim nu pentru hrana cea stricăcioasă, ci pentru hrana care rămâne spre viaţa veşnică. Unde sunt acum tăierile animalelor necuvântătoare, mirosurile de carne friptă, mâncărurile cele bogate şi ostenelile bucătarilor? Unde sunt cei care străbat străzile şi cu glasurile lor cele necurate împut aerul? Unde sunt cei care bat [din tobe] şi cântă din fluier prin case şi pe la mese şi cei care le sunt devotaţi şi li se adaugă aplaudând, şi care, în [sunet] de timpane şi de fluiere, se umplu fără control din [mâncărurile] puse înainte?

${ }^{13}$ Sfântul Simeon Noul Teolog, Cateheze, Scrieri II, trad. Ioan I. Ică jr, Sibiu, Edit. Deisis, 1999, p. 271. 
Unde sunt cei care îşi petrec zilele şi nopţile în petreceri, care cercetează unde este de băut, care-şi ţin companie unii altora la beţie şi la faptele cele ruşinoase ale beţiei? Când se statorniceşte postul, toate cele rele se duc şi toate cele bune vin în locul lor. În locul cântecelor spurcate, acum gura cântă un psalm sfânt. În locul râsetelor nedemne, acum sunt de faţă tristeţea cea mântuitoare şi lacrimile. În locul drumurilor lipsite de rost şi a vagabondajelor, [acum] există un singur drum comun pentru toţi, şi anume cel către sfânta biserică a lui Hristos. Căci după cum lăcomia pântecelui face să răsară roiul cel fără de număr al păcatelor, la fel postul este rădăcina tuturor virtuţilor şi început al poruncilor dumnezeieşti”"

Lăcomia la mâncare reprezintă, aşadar, motorul care declanşează „,cântecele curveşti şi dansurile satanice”. Şi acest fel de cântece sunt o exprimare a trăirilor sufleteşti, însă sunt forme denaturate de manifestare a unei bucurii pervertite. Din ansamblul acestor bucurii pervertite fac parte şi ,bătăile de tobe, cântecele din fluier" din locuinţele private sau din locurile publice, sunetele de timpane. Toate aceste manifestări marchează starea polis-ului înainte de începerea Postului Mare. În momentul în care Postul se apropie, Sfântul Grigorie constată că toate acestea sunt înlocuite, într-un act general de pocăinţă (prezentat, probabil, într-o manieră oarecum exagerată), cu manifestări duhovniceşti ale unei alte bucurii, de data aceasta fiind vorba de o bucurie veritabilă, duhovnicească. Locul „cântecelor spurcate” este luat de citirea sau cântarea psalmilor, reper important pentru maniera în care asumarea perioadei pre-pascale era un gest de reconversie interioară cu valenţe publice.

În „Omilia a IX-a”, Sfântul Grigorie explică rolul de instrument al cântării, care îl pune pe cel care execută sau ascultă cântarea în starea de prezenţă în faţa lui Dumnezeu:

„Să facem postul, psalmodierea şi rugăciunea noastră ca şi cum Dumnezeu Însuşi ar fi de faţă şi s-ar uita la noi,

${ }^{14}$ Sfântul Grigorie Palama, Omilii I, p. 94. 
ştiind că nici postul, nici psalmodierea şi nici rugăciunea nu pot să ne mântuiască prin ele însele, ci împlinirea acestora înaintea lui Dumnezeu. Căci astfel, ochii lui Dumnezeu, privindu-ne, ne sfințesc, după cum soarele încălzeşte cele pe care le luminează. Iar acestea se fac înaintea lui Dumnezeu atunci când mintea se uită la El cu încordare, şi în timp ce se uită, posteşte, psalmodiază şi se roagă. Căci [dacă] atunci când suntem în timpul rugăciunii şi al psalmodierii, uneori mintea se îndreaptă neabătut către Dumnezeu, iar alteori cade şi se tulbură, trebuie să înţelegem că încă nu ne-am dedicat cu totul lui Dumnezeu, şi că scopul celor făcute de noi nu se află în întregime în [concordanţă] cu legea Domnului. De aceea, pe cât cădem din faptele dreptăţii, pe atât nu putem rămâne înaintea ochilor lui Dumnezeu. [Pentru că] zice: $\mathrm{Nu}$ vor sta călcătorii de lege înaintea ochilor Mei [Ps. 5, 5]. Totuşi, când zăcem răniţi la pământ, să-L chemăm pe Domnul, Care poate să pună balsam şi feşe peste rănile noastre"15.

Cântarea nu este un scop în sine. Din nou, nu asistăm la o devalorizare a cântării, ci la o reaşezare a ei în cadrele precise ale funcţionalităţii. Cântarea nu mântuieşte, spune sfântul Grigorie, însă este un instrument necesar pentru concentrarea minţii şi orientarea acesteia către rugăciunea curată. Acelaşi lucru avea să îl spună şi sfântul Simeon Noul Teolog şi despre alte instrumente duhovniceşti, fără ca prin aceasta să le devalorizeze: „Să nu ne încredem numai în cutare sau cutare lucrări şi virtuţi, adică în posturi sau privegheri sau culcări pe jos sau alte felurite rele pătimiri, şi să dispreţuim această lucrarea a poruncilor Domnului ca şi cum am putea să ne mântuim numai prin acelea"16.

Împlinirea cântării „ca în faţa lui Dumnezeu” ajută mintea să se adune în sine şi prin această adunare în sine, ea îşi împlineşte datoria de a se orienta exclusiv către Dumnezeu. Abaterea de la această datorie, care este, în fond, firescul activităţii minţii, reprezintă o scădere a curăţiei şi deplinătăţii rugăciunii şi un semn

${ }^{15}$ Sfântul Grigorie Palama, Omilii I, p. 118-119.

${ }^{16}$ Sfântul Simeon Noul Teolog, Cateheze, Scrieri II, p. 137. 
că instrumentele folosite nu sunt valorizate întotdeauna ca instrumente, ci ca scopuri în sine. Cântarea bisericească psaltică autentică are tocmai acest rol, de a ajuta mintea să se adune în sine şi să se înalţe neabătut către Dumnezeu. Oricât ar fi de frumoase şi tentante alte tradiţii muzicale bisericeşti, ele se abat de la scopul principal al cântării şi anume de a fi un instrument eficace pentru ajutarea minţii să se dedice în întregime rugăciunii. Derivele muzicale sentimentaliste sau estetice pot deveni astfel deosebit de periculoase pentru integritatea felului în care mintea se poate servi de cântare pentru a-şi atinge scopul duhovnicesc.

Lucrul acesta îl spune sfântul Grigorie Palama şi în „Omilia a XX-a":

„Dar voi, adunaţi fiind în biserica lui Dumnezeu, încingeţi mijloacele cugetului vostru, după cuvântul lui Petru [...]. Căci nu este posibil ca cel care stă în sfânta lui Dumnezeu biserică şi îşi adună mintea, şi şi-o înalţă către Dumnezeu, şi îşi exersează cugetarea cu sfintele cântări, şi şi-o dedică acestora, de la început până la sfârşit, să nu fie schimbat cu schimbarea dumnezeiească, pe măsura exersării [atenţiei] faţă de Dumnezeu şi de cuvintele dumnezeieşti. Căci prin exersarea aceasta se naşte în inimă o căldură care, izgonind ca pe nişte muşte gândurile cele rele, produce în suflet pace duhovnicească şi mângâiere, şi aduce sfinţ̧ire trupului" ${ }^{17}$.

Exersarea atenţiei şi a cugetării cu ,sfintele cântări” este deosebit de importantă pentru adunarea minţii în sine, care atrage după sine „schimbarea dumnezeiască”. Este interesant faptul că sfântul Grigorie vede o corespondenţă clară între nivelul şi calitatea exersării atenţiei şi darul primit în schimbul acestei exersări, adică „schimbarea cea dumnezeiască”. Asumarea interioară a sfintelor cântări presupune exercitarea completă a atenţiei în intervalul în care aceste cântări sunt executate. Din punctul de vedere al psaltului, lucrul acesta înseamnă o foarte bună cunoaştere a tehnicii cântării, precum şi o pregătire minuţioasă a fiecărei slujbe. Aceste

${ }^{17}$ Sfântul Grigorie Palama, Omilii I, p. 270. 
două aspecte îl eliberează pe psalt de grija acaparatoare pentru bunul mers al cântării, lăsându-i mintea liberă pentru adâncirea în cântare, şi implicit în rugăciune. Din punctul de vedere al celui care participă interior la cântare, exersarea atenţiei presupune grija pentru ca mintea să nu fie distrasă de şuvoiul gândurilor de orice fel. Astfel, şi psaltul şi monahul sau creştinul care nu au această ascultare se află într-o împreună lucrare de exercitare a atenţiei fără de care nu se poate realiza o participare adecvată la sfintele slujbe.

În „Omilia a X-a”, sfântul Grigorie face un elogiu al cântării împlinite cu înţelegere şi străpungere de inimă:

„Şi ca să las acum deoparte virtuţile cele mai de seamă, atunci când mă înfăţişez împreună cu voi înaintea lui Dumnezeu în sfânta biserică, şi când, întorcându-mă, îi văd pe cei care cu înţelegere şi cu străpungere de inimă înalţă către Dumnezeu imne şi rugăciuni, sau pe vreunul care tace, stând adâncit în sine şi ascultând, singură vederea aceasta pe dată mă insuflă, mă umple de bucurie şi dau slavă lui Hristos, Tatăl Cel din ceruri, fără de Care nimeni nu poate să facă nimic din cele bune şi prin Care se împlineşte totul pentru oameni”'18.

Observăm şi în acest pasaj că „străpungerea inimii” este prezentă atât în cântare, cât şi în ,,adâncirea de sine şi ascultarea” [cântărilor]. Starea de pocăinţă adâncă trebuie să însoţească cântarea de la strană, iar acesteia i se adaugă şi atenţia la textul cântat. „Înţelegerea” de care vorbeşte sfântul Grigorie este tocmai condiţia pentru adunarea minţii în sine şi transferarea activităţii minţii de la risipirea în gânduri la rugăciunea concentrată.

În aceeaşi „Omilie”, sfântul Grigorie îi ceartă pe cei care vin la slujbe şi afişează o atitudine de indiferenţă faţă de conţinutul cântărilor.

„Dar ce vom spune acum celor care nu stau în tăcere, nici nu psalmodiază împreună [cu noi], ci [vin aici] ca să se întâlnească unii cu alţii, amestecând slujirea noastră

18 Sfântul Grigorie Palama, Omilii I, p. 130. 
duhovnicească către Dumnezeu cu vorbăria [lor] cea lumească, astfel încât nu numai că ei nu ascultă cuvintele cele sfinte şi însuflate de Dumnezeu, dar îi împiedică şi pe cei care vor să asculte? Până când, voi aceştia, veţi şchiopăta de amândouă picioarele? [III Rg. 18, 21], ar spune Ilie Tesviteanul. Pentru că vreţi să veniţi [aici] şi pentru rugăciune, şi pentru cuvintele cele lumeşti şi nepotrivite, şi cu siguranţă nu faceţi bine nici una, nici alta, ci prin acestea le stricaţi pe celelalte, sau mai degrabă vă stricaţi voi înşivă, unii prin alţii. Până când nu o să vă abţineţi de la cuvintele deşertăciunii în acest loc şi veţi face din casa rugăciunii, casă de negustorie sau de cuvânt al patimii, tocmai această casă în care sunt spuse şi ascultate cuvintele vieţii veşnice, atât cele [spuse şi ascultate] de noi, care cerem de la Dumnezeu cu nădejde neruşinată viaţa veşnică, cât şi cele [spuse şi ascultate] de Dumnezeu, Care dă [viaţa veşnică] celor care o cer cu tot sufletul şi cugetul - însă nu şi celor care, cum se spune, nu-s în stare nici măcar limba să şi-o urnească întreagă spre cerere?"19.

Pentru sfântul Grigorie Palama nu există o cale de compromis între adâncirea în rugăciune, potenţată de cântare, şi rispirea în rugăciune produsă de amestecul minţii cu gândurile de zi cu zi. Starea în tăcere sau împreună-psalmodierea exclud orice altă preocupare în timpul rugăciunii, cel chemat să ia aminte la cuvintele rugăciunii trebuie să îşi asume această stare, chiar dacă ea presupune un efort important de detaşare de cele lumeşti. Ba, mai mult, spune sfântul Grigorie, nici măcar cele lumeşti nu vor fi planificate sau gândite în mod corespunzător, pentru că mintea nu va putea asuma integral şi concomitent două realităţi diametral opuse. Cererea în rugăciune, asumată în mod total, aduce, în schimb, viaţă veşnică şi pregustarea Împărăţiei lui Dumnezeu.

Riscul împrăştierii în rugăciune şi cântare poate avea consecinţe dramatice în viaţa creştinului care consideră că poate acţiona în mod neglijent în situaţiile în care atenţia şi înţelegerea sunt vitale pentru felul în care decurge rugăciunea. Sfântul Grigorie

${ }^{19}$ Ibidem, p. 130-131. 
este, de altfel, destul de critic şi categoric cu cei care nu îşi asumă deplin această concentrare:

„Fraţilor, acum jertfa noastră către Dumnezeu nu se mai face prin foc, ca pe vremea lui Moise, ci se săvârşeşte prin cuvânt. Atunci, aşadar, când Dumnezeu primea jertfa adusă prin foc, cei dimpreună cu Core, care s-au răsculat împotriva lui Moise şi care au adus de afară foc străin, au fost arşi de tot de focul cel sfânt, care de la sine a sărit asupra lor. Să ne temem dar şi noi, că dacă vom aduce din afară cuvinte străine în acest jertfelnic duhovnicesc al lui Dumnezeu, vreau să spun în biserică, vom fi osândiţi pentru totdeauna de cuvintele dumnezeieşti ce sunt în ea, făcându-ne vrednici din această pricină de glasul acela de temut şi de osândă. Da, să ne temem, rogu-vă, şi câtă vreme suntem aici [în biserică] să aducem cerere, stând cu frică înaintea lui Dumnezeu. Iar după ce ieşim de aici, să dăm dovadă mai departe de schimbarea în bine a obiceiurilor noastre, nelăsându-ne biruiţi de câş̧iguri, mai ales dacă sunt nedrepte, fugind de jurăminte, mai ales dacă sunt mincinoase, îndepărtându-ne de cuvintele cele de ruşine, şi cu atât mai mult de faptele cele ruşinoase, de calomnii, de înşelăciune şi de îngâmfare, educând şi mişcând fiecare mădular şi fiecare simţire cu ajutorul minţii celei de Dumnezeu înţelepţite, purtând şi înălţând trupul cu cuvântul şi cu frica cea îndumnezeiască, şi nu lăsându-ne traşi în jos şi supuşi de către trup poftelor lui cele pământeşti şi de batjocură, învăţând şi cunoscând de la Pavel că dacă vom trăi după trup, vom muri, iar dacă vom ucide cu duhul lucrările trupului, vom trăi în veci”20.

Am redat acest fragment destul de amplu tocmai pentru că este interesantă paralela pe care o face sfântul Grigorie între focul străin adus în chip nevrednic în vremea lui Moise şi ,cuvintele străine" care pot pătrunde în taina Bisericii prin neglijenţa celor care tratează momentul rugăciunii cu indiferenţă.

„Cuvintele străine” despre care vorbeşte sfântul Grigorie Palama pot fi interpretate (deşi sfântul nu face acest lucru în mod

${ }^{20}$ Sfântul GrigORIE PALAMA, Omilii I, p. 130-131. 
explicit) şi ca moduri de cântare străine de ethosul liturgic, care pot întoarce mintea de la concentrarea în rugăciune şi o pot mişca către stări străine şi chiar periculoase (ne referim, în special, la denaturări care stimulează nepermis de mult sentimentalismul sau gustul estetic). Aceste feluri de „cuvinte străine” sunt deosebit de periculoase atât pentru echilibrul liturgic, cât şi pentru demersul de care amintim în mod repetat în acest studiu: adunarea minţii în sine. O muzică liturgică care face apel la sentimentalisme va crea o dispoziţie interioară bolnăvicioasă, incapabilă să discearnă adevărata pocăinţă de stările psihologice înşelătoare. De asemenea, o muzică liturgică care face apel la simţul estetic va distorsiona întreg simţul duhovnicesc al ascultătorului neexperimentat, deturnându-l de la adâncirea în sine către atitudinea admirativă declanşată de acest tip de cântare. Mai ales în cazul celor neexperimentaţi duhovniceşte, riscul este deosebit de mare. Neatenţia la felul în care lucrează mintea poate produce dezechilibre grave, iar muzica neadecvată liturgic poate constribui masiv la aceste dezechilibre. O bună parte a literaturii filocalice acordă o importanţă deosebită trezviei în rugăciune, şi menţionăm aici doar câteva atenţionări ale sfântului Isihie cu privire la aceste aspecte: „ $\mathrm{Cu}$ cât eşti mai atent la gândire, cu atât te vei ruga lui Dumnezeu cu dor, şi, iarăşi, cu cât scrutezi gândirea în chip nepăsător, cu atât te vei îndepărta şi de Iisus. Aşa cum primul lucru luminează în chip culminant văzduhul gândirii, tot aşa şi abaterea de la trezie şi de la dulcea chemare a lui Iisus o întunecă în chip natural cu totul" 21 .

Orice cântare care nu respectă cerinţele liturgice şi neptice poate provoca această îndepărtare de rugăciunea minţii şi abaterea de la trezvie - pas important în denaturarea nu doar a lucrării lăuntrice a minţii, ci a întregului ethos liturgic care poate deveni o scenă nedorită a diferitelor manifestări de virtuozitate lipsite de înţelegerea dinamicii participării la slujbele Bisericii. De altfel, sfântul Ioan Casian avertizase cu sute de ani înainte asupra riscului

${ }^{21}$ Capitolele Sfântului Isihie, în FILOTEI SinAITUl, Trezia minţii şi cerul inimii. Integrala scrierilor, trad. Ioan I. Ică jr., Sibiu, Edit. Deisis, 2009, p. 159. 
manifestărilor personale de natură psihologică sau fizică care pot perturba atât liniştea celorlalţi, cât şi propria adâncire în rugăciune:

„Deci când se adună să facă slujirile mai sus pomenite, pe care le numesc « sinaxis ", toţi păstrează atâta linişte, încât, deşi se strânge la un loc un număr mare de monahi, ai crede că nu se mai află niciun om înăuntru, în afară de cel care, sculându-se, intonează psalmul la mijloc, şi asta mai ales când se încheie slujba. În tot acest timp nimeni nu scuipă, nu-şi drege glasul, nu tuşeşte, nu cască a somn cu fălcile şi gura deschise. nu se scoate niciun geamăt, niciun suspin, care să poată stânjeni pe cei de faţă, nu se aude niciun glas în afară de cel al preotului, care încheie rugăciunea, sau de cel pe care, cu mintea în extaz l-ar putea scăpa cineva printre buze şi să-l strecoare pe nesimţite inimii sub clocotul adând şi de nebiruit al spiritului" 22 .

Cântarea bisericească nu presupune o antrenare activistă, ci reunirea puterilor sufleteşti în tăcerea minţii. Excepţiile sunt date doar de preaplinul extazului, atunci când mintea nu îşi poate reţine un anumit fel de exteriorizare discretă.

\section{Cântarea - mod de preaslăvire a tainelor dumnezeişti}

Sfântul Grigorie nu se rezumă doar la atenţionările prezentate mai sus, care au în vedere raportarea la înţelegerea corectă a poziţionării faţă de cântare. Pentru dascălul isihast, cântarea este şi împreună slăvire a tainelor negrăite pe care Dumnezeu le împlineşte

22 Sfântul IOAN CASIAN, Scrieri alese, trad. Vasile Cojocaru şi David Popescu (Părinţi şi scriitori bisericeşti, 57), Bucureşti, Edit. Institutului Biblic şi de Misiune al Bisericii Ortodoxe Române, 1990, p. 126. În continuarea acestui pasaj, sfântul Ioan Casian precizează: „Pe cel ajuns a se răci cu inima, care se roagă cu larmă sau scoate din gât ceva din cele spuse mai sus, şi îndeosebi este prins de căscături, ei îl declară dublu vinovat: mai întâi că îşi face rugăciunea cu nepăsare şi în al doilea rând că, prin zgomotul lui nestăpânit, abate şi atenţia altuia, care neîndoielnic ar fi putut să se roage mai cu înfocare". 
cu omul. Astfel, în prima „Omilie”, descrie cântarea îngerilor drept o cântare care dezvăluie modul în care Dumnezeu alege să coboare la om: „Imnul cântat de îngeri la naşterea Lui arată că a venit la noi din ceruri aducând pacea: «Slavă, zic îngerii, întru cei de sus lui Dumnezeu şi pe pământ pace, întru oameni bunăvoire [Lc. 2, 14]»" "23. Ingerii se manifestă doxologic, având în centrul acestei manifestări tocmai cântarea, imnul de slavă care tâlcuieşte în chip negrăit taina păcii corelată întrupării Mântuitorului.

Slava datorată lui Dumnezeu se manifestă prin cântare. Uimirea în faţa creaţiei produce cântare dumnezeiesc insuflată, iar cel care înţelege pronia lui Dumnezeu, înţelepciunea Acestuia şi raţionalitatea creaţiei devine un admirator plin de bucurie care se exteriorizează tocmai în cântarea liturgică normativă. În „Omilia a XIV-a”, sfântul Grigorie vorbeşte atât de lumea creată ca izvor al imnului, cât şi de tainele nepătrunse ale lui Dumnezeu, care prin întrezărirea lor produc aceeaşi mişcare de exteriorizare a bucuriei: „Căci dacă toate cele care există sunt pline de minunăţie, şi venirea lor de la nefiinţă la fiinţă este un lucru dumnezeiesc şi vrednic de a fi cinstit prin multe imne, cu cât mai minunat şi mai dumnezeiesc şi mai necesar a fi lăudat de noi este că Dumnezeu devine ceva din cele ce sunt" 24 . Peste şase veacuri, sfântul Siluan Athonitul avea să insiste din nou asupra acestui impuls pe care frumuseţea şi raţionalitatea creaţiei, pe de o parte, şi întrezărirea tainelor dumnezeieşti, pe de altă parte, îl produc în sufletului celui atins în chip lucrător de har:

„Din copilărie am iubit şi lumea şi frumuseţea ei. Iubeam pomii şi grădinil înverzite, iubeam câmpiile şi toată frumuseţea zidirii lui Dumnezeu. Îmi plăcea să privesc strălucirea norilor, să-i văd trecând în înălţimile albastre. Dar de când am cunoscut pe Domnul meu şi $\mathrm{El}$ a robit sufletul meu, totul s-a schimbat în mine. Nu mai vreau să privesc această lume, căci sufletul meu este neîncetat atras spre lumea în care locuieşte Domnul. Aşa cum pasărea doreşte să zboare din colivia ei cea strâmtă spre tufişurile dese, aşa arde şi sufletul meu de dorinţa de a vedea

${ }^{23}$ Sfântul Grigorie Palama, Omilii I, p. 31.

${ }^{24}$ Ibidem, p. 176. 
din nou pe Domnul, tânjeşte după El şi strigă: «Unde eşti, Lumina Mea? Vezi că te caut cu lacrimi»»"25.

Preamărirea lucrării lui Dumnezeu presupune aşadar o exteriorizare. Această manifestare exterioară este prezentă, după sfântul Grigorie Palama, atât la diferite personaje biblice, cât şi la creştinii contemporani lui: „Dar Simeon a venit în Templu, L-a întâmpinat şi L-a luat în braţe pe Acest Prunc ceresc şi pământesc; I-a adus, ca unui Dumnezeu, imn şi cerere"26. Simeon Îi aduce lui Dumnezeu imn şi cerere într-un moment cheie al existenţei sale: momentul adeveririi că Fecioara a putut să nască, fapt ce a rispit întru totul dilema care îl chinuise timp îndelungat pe Simeon. Această cântare a lui Simeon este exemplu şi pentru creştinii contemporani, care sunt chemaţi să preaslăvească tainele lui Dumnezeu prin închinare, bucurie şi cântare (subînţeleasă prin „săltarea fără încetare" de care aminteşte sfântul Grigorie în pasajul care urmează):

„Dar noi, plecându-ne şi inimile dimpreună cu genunchii, veniţi să ne închinăm împreună cu psalmistul şi profetul David la locul unde au stat picioarele Lui [Ps. 131, 7], unde au fost întinse mâinile Lui care cuprind totul şi unde a fost arătat trupul Său cel începător de viaţă. Şi închinându-ne [Crucii] cu credinţă şi sărutând-o, să [ne] atragem şi să păstrăm belşugul sfinţeniei [revărsate] din ea, pentru ca la preaslăvita venire ce va să fie a Domnului şi Dumnezeului şi Mântuitorului nostru Iisus Hristos, văzând-o venind înainte întru slavă, să ne bucurăm şi să săltăm fără încetare, având parte de şederea cea de-a dreapta şi de glasul cel fericit ce a fost făgăduit şi de binecuvântare, întru slava Fiului lui Dumnezeu Care a fost răstignit pentru noi cu trupul"27.

Cântarea însoţeşte nu doar preamărirea lucrărilor lui Dumnezeu, ci şi cinstirea persoanelor care şi-au asumat pe deplin

${ }^{25}$ Cuviosul Siluan Athonitul, Între iadul deznădejdii şi iadul smereniei, trad. Ioan I. Ică jr., Alba Iulia, Edit. Deisis, 1994, p. 56.

${ }^{26}$ Sfântul Grigorie Palama, Omilii I, p. 79.

${ }^{27}$ Ibidem, p. 153. 
vieţuirea potrivit lucrării harului: „Dacă pomenirea fiecăruia dintre sfinţi, după cum am spus, se săvârşeşte de noi cu imne şi cu elogii pe măsură, cu cât mai mult [se cuvine a cinsti pomenirea] lui Petru şi Pavel, corifeii cei mai înalţi ai corului corifeic al apostolilor?"28. Credincioşii sunt chemaţi să cânte pe fiecare dintre sfinţi cu imne pe măsura vieţuirii lor. Imnul este astfel o expresie de recunoaştere a faptului că omul este chemat la îndumnezeire. Troparele, condacele, canoanele nu sunt simple expresii ale unei efuziuni sentimentale produse de caracterul înalt moral al persoanelor care constituie subiectul imnelor, ci sunt monumente de teologhisire adevărată, în care se preamăreşte tocmai lucrarea lui Dumnezeu prin care se deschide omului calea îndumnezeirii.

Mai presus însă de cinstirea sfinţilor prin cântări se află cinstirea Maicii Domnului. Acolo unde raţiunea se opreşte şi nu poate pătrunde mai departe sau nu poate explica suficient, intervine cântarea. Faptul acesta este afirmat de sfântul Grigorie Palama în Omilia a XXXVII-a: „Dar dacă totuşi nu este [cu putinţă] a spune cele mai presus de cuvânt, cu putinţă este, din iubire de oameni, a înălţa imne celor cântate, cu putinţă este şi a atinge [prin ele] cele nicidecum atinse, a întoarce datoria prin cuvinte [de laudă] şi a ne împlini dorul faţă de Născătoarea de Dumnezeu prin cântări după putere"29. Sfântul Grigorie îşi mărturisise mai înainte neputinţa de a descrie suficient în predica sa la sărbătoarea Adormirii Maicii Domnului „măreţiile” Maicii Domnului şi de aceea afirmă acum că doar cântarea este cea care într-un anumit fel este capabilă ,să atingă cele neatinse". Dacă în cazul sfinţilor, lauda prin cântare este un imperativ, cu atât mai mult datoria liturgică impune acest lucru în cazul Maicii Domnului: „Iar dacă cinstită este moartea cuvioşilor [Ps. 115, 6] şi pomenirea dreptului cu laude [Pilde 10, 7], cu cât mai mult se cade să facem cu laude dintre cele mai mari pomenirea Sfintei sfinţilor, a Celei prin care vine sfinţilor toată sfinţirea, a Pururea Fecioarei şi Maicii lui Dumnezeu?"30.

28 Sfântul Grigorie Palama, Omilii II, trad. Roger Coresciuc, Iaşi, Edit. Doxologia (în curs de publicare), p. 91.

${ }^{29}$ Ibidem, p. 189.

${ }^{30}$ Ibidem, p. 190. 
Însăşi omilia aceasta a sfântului Grigorie Palama, ca de altfel toate omiliile dedicate Maicii Domnului, este imprimată de aspecte poetice sau latreutice pe care sperăm să le putem analiza într-un alt studiu. Redăm aici un singur fragment din „Omilia a XXXVII-a”, important pentru o astfel de analiză:

„Ce cuvânt poate zugrăvi, Maică a lui Dumnezeu Fecioară, frumuseţea Ta cea dumnezeiesc strălucitoare? Căci cele ale tale nu pot fi hotărnicite de cugete sau de cuvinte, pentru că toate covârşesc şi cuget, şi cuvânt! Dar cu putinţă este să fii cântată, tu, cea care primeşti cu iubirea de oameni [cântarea]! Fiindcă tu eşti loc al tuturor harurilor, plinătatea a toată frumusețea şi bunătatea, tablă şi icoană însufleţită a tot binele, şi a toată bunătatea, ca una care singură ai fost învrednicită în chip concentrat de harismele Duhului sau mai degrabă, ca una care singură ai avut în chip minunat în cele dinlăuntru ale tale pe Cel în Care sunt vistieriile tuturor acestor [harisme] şi te-ai făcut Lui cort minunat. Iar acum, prin moarte, ai trecut de aici către nemurire şi cu dreptate teai mutat de pe pământ la cer, ca să fii împreună locuitoare cu Acesta în corturile cele mai presus de ceruri de-a pururea, grijindu-te de acolo de moştenirea ta şi cu rugăciunile tale cele neadormite către Dânsul făcându-L milostiv tuturor"31.

Şi câteva momente importante din lucrarea mântuitoare a lui Hristos sunt amintite de sfântul Grigorie Palama în legătură cu imnele şi cântarea. Astfel, la Intrarea în Ierusalim, poporul îl întâmpină pe Hristos cu cântări. Imnul „Osana”, tâlcuit de dascălul isihast în „Omilia a XV-a”, este o expresie a împreună-cântării îngerilor cu oamenii în elanul provocat de taina Întrupării şi mântuirii:

„Deci, după ce 1-a înviat pe Lazăr din morţi, împăratul, călare pe un asin, a intrat apoi în Ierusalim, şi aproape îndată toţi cei din popor - copii, bărbaţi, bătrâni - aşternând pe jos haine şi purtând stâlpări de finic, care sunt semne ale biruinţei, şi întâmpinându-L ca pe Cel care era Făcător de

${ }^{31}$ Ibidem, p. 196-197. 
viaţă şi Biruitor al morţii, au căzut la picioarele Lui şi L-au însoţit, cântând într-un glas, nu numai în afara, ci şi înăuntrul îngrăditurilor Templului: Osana, Fiul lui David, Osana întru cei de sus. Osana este un imn care se înalţă către Dumnezeu, căci tălmăcit înseamnă: Mântuieşte, Doamne. Iar adăugirea întru cei de sus arată că [Dumnezeu] este cântat nu numai pe pământ şi nu numai de către oameni, ci şi întru cele înalte, de către îngerii cereşti. Ei însă nu numai că Îl cântă astfel şi Îl teologhisesc, ci se şi împotrivesc, prin cele care urmează, judecăţii cărturarilor şi a fariseilor, celei de rău voitoare şi luptătoare contra lui Dumnezeu, precum şi pretextelor lor celor ucigaşe" 32 .

Cântarea de slăvire nu este însă doar o cântare - expresie a efuziunii de moment, ci este teologhisire. Faptul că nu doar oamenii cântă, ci şi îngerii, întăreşte convingerea că imnele liturgice actuale nu sunt expresia unui gest uman autonom, ci sunt rezultatul unei insuflări dumnezeieşti.

La fel, ziua Cincizecimii este marcată de cântare. În „Omilia a XXIV-a”, sfântul Grigorie descrie momentul premergător pogorârii Duhului Sfânt drept un moment marcat de „luarea aminte la rugăciune şi la imnele cele către Dumnezeu":

„Când s-a împlinit a cincizecea zi de la Înviere - a cărei pomenire ne stă de faţă acum -, fiind adunaţi toţi ucenicii în acelaşi loc şi fiind într-un cuget în partea de sus a templului aceluia, dar şi fiecare dintre aceştia fiind adunat în partea de sus a lui însuşi, [adică] în propria minte - căci erau dedicaţi şi cu luare aminte la rugăciune şi la imnele cele către Dumnezeu -, s-a făcut, zice Evanghelistul Luca, din cer, fără de veste, un vuiet, ca o suflare de vânt ce vine repede şi a umplut casa unde şedeau ei [Fapte 2, 2]"33.

Ucenicii erau adunaţi în ,partea de sus a propriului sine”, adică în minte, şi doar aşa puteau acorda atenţia cuvenită rugăciunii

\footnotetext{
${ }^{32}$ Sfântul GrigOrIE PALAMA, Omilii I, p. 191.

${ }^{33}$ Sfântul Grigorie Palama, Omilii II, p. 49.
} 
şi cântării. Fără această adunare în sine, în ,,partea de sus a sinelui”, nu este posibilă nici rugăciunea curată şi nici psalmodierea fără împrăştiere. Această neîmprăştiere din ziua Cincizecimii este premergătoare venirii Duhului Sfânt şi ea este paradigmatică pentru orice demers isihast şi liturgic.

Cântarea marchează aşadar şi lauda adusă lui Dumnezeu şi lauda adusă sfinţilor. Ea este o constantă a vieţii duhovniceşti şi se regăseşte în deplinătatea ei în viaţa monahală. Fecioria este împletită cu rugăciunea, cu atenţia, cu străpungerea sufletului, stări absolut necesare şi pentru dezvoltarea ,prezenţei” în citirea sau cântarea psalmilor, a imnelor şi a cântărilor duhovniceşti. În „Omilia a XLII-a” întâlnim o astfel de descriere succintă pe care sfântul Grigorie Palama o face vieţuirii monahale:

„Fecioarelor care aţi făgăduit [să duceţi] viaţă monahală şi cele care v-aţi întors, bine făcând, de la viaţa conjugală la împreună vieţuirea cea feciorelnică, şi, pe scurt, câte aţi ales din dorinţa de pocăinţă să vieţuiţi împreună cu acestea [cu fecioarele], vieţuiţi în toate după Dumnezeu, de dragul Fecioarei care pentru noi s-a născut acum şi care a născut întru feciorie, sub timp, după trup, pe Cel Născut mai înainte de veci din Tată feciorelnic, trăind numai pentru ea şi pentru Dumnezeu[-Fiul], Cel care S-a întrupat din ea, privind numai la El, făcându-L doar pe El desfătarea voastră, bucurându-vă întru nădejde, răbdând în necaz, supunându-vă întâi-stătătoarelor voastre, slujind unele altora, sârguindu-vă pentru pacea dintre voi, dedicându-vă fără încetare cu atenţie, rugăciune şi străpungerea sufletului psalmilor, imnelor şi cântărilor duhovniceşti, fiind curate şi fecioare, şi cu trupul, şi cu sufletul, şi cu toate simţurile şi înţelegerea, şi arătând prin toate o cugetare şi o petrecere duhovnicească şi feciorelnică. Astfel, după [cuvântul] psalmului, urmând Maicii lui Dumnezeu, veţi ajunge aproape de Ea şi veţi intra în templul cel nefăcut de mână al Împăratului cerurilor, în cămara de nuntă cea mai presus de lume şi veşnică a nestricăciunii” ${ }^{34}$.

${ }^{34}$ Ibidem, p. 259. 
Maica Domnului este model isihast al vieţuirii feciorelnice, devenind paradigmă, prin virtuţile ei, oricărui demers ulterior de asumare a monahismului. Remarcăm şi aici, încă o dată, faptul că sfântul Grigorie se referă la „atenţie” ca la un reper deosebit de important pentru monah (dar, bineînţeles, şi pentru creştinii mireni). Monahul este chemat să facă ascultare, să rabde, să slujească, să întreţină duhul păcii, să se bucure de propriul parcurs, dar în acelaşi timp este chemat să fie atent, să nu-şi risipească mintea, să nu dezerteze de la concentrarea fără de care rugăciunea sau cântarea devin simple lucruri formale.

\section{Concluzii}

Deşi „Omiliile” Sfântului Grigorie Palama nu ne oferă foarte multe informaţii despre cântarea bisericească din secolul al XIV-lea, putem totuşi să identificăm câteva elemente clare care să ne ajute la creionarea cadrului general cu privire la cântare. Astfel, cântarea nu era considerată drept un adaos lipsit de interes sau de necesitate, ci i se acorda importanţa cuvenită. Sfântul Grigorie însuşi s-a îngrijit de cele necesare bunei activităţi a psalţilor sau a grupurilor de cântăreţi (fie din Athos, fie din Salonic). Cântarea era privită în strânsă legătură cu trezvia minţii şi cu atenţia în rugăciune. Pentru a crea cadrul necesar rugăciunii liturgice, atât cântărețul de la strană, cât şi cel care asculta cântarea trebuiau să fie deja imprimaţi de roadele rugăciunii neîntrerupte practicate în afara cadrului strict liturgic. Prin cântare se lăudau adevărurile tainelor dumnezeieşti, momentele importante din iconomia Întrupării, tainele nepătrunse ale Maicii Domnului, vieţuirile sfinţilor. Bineînţeles, nu am selectat toate textele din „Omilii” cu referire la cântare. În special cele din omiliile rostite la sărbătorile Maicii Domnului vor constitui baza unui viitor studiu cu privire la forma latreutică în care îşi alcătuia sfântul Grigorie panegiricele mariale. 


\section{Bibliografie}

\section{Izvoare}

1. Sfântul Grigorie Palama, Omilii I, trad. Roger Coresciuc, Iaşi, Edit. Doxologia, 2019.

2. Sfântul GRIGORIE PALAMA, Omilii II, trad. Roger Coresciuc, Iaşi, Edit. Doxologia (în curs de publicare).

\section{Bibliografie secundară}

3. Sfântul IOAN CASIAN, Scrieri alese, trad. Vasile Cojocaru şi David Popescu (Părinţi şi scriitori bisericeşti, 57), Bucureşti, Edit. Institutului Biblic şi de Misiune al Bisericii Ortodoxe Române, 1990.

4. Sfântul GRIGORIE SinAITUL, Despre felul cum trebuie să şadă la rugăciune, în Filocalia sfintelor nevoinţe ale desăvârşirii, vol. VII, trad. D. Stăniloae, Bucureşti, Edit. Humanitas, 1999.

5. FILOTEI, preasfântul patriarh al Constantinopolului, Cuvânt la cel intru sfinţi Părintele nostru Grigorie, arhiepiscopul Tesalonicului, în GrIGORIE Palama, Tomosuri dogmatice. Viaţa. Slujba. Scrieri I, trad. Ioan I. Ică jr., Sibiu, Edit. Deisis, 2009.

6. Capitolele Sfântului Isihie, în FILOTEI SinaITUL, Trezia minţii şi cerul inimii. Integrala scrierilor, trad. de Ioan I. Ică jr., Sibiu, Edit. Deisis, 2009.

7. Sfântul Simeon Noul TeOlog, Cateheze, Scrieri II, trad. Ioan I. Ică jr, Sibiu, Edit. Deisis, 1999.

8. TeOliPT AL FILADELFIEI, Despre ostenelile vieţii călugăreşti, în Filocalia sfintelor nevoinţe ale desăvârşirii, vol. VII, trad. D. Stăniloae, Bucureşti, Edit. Humanitas, 1999.

9. Cuviosul Siluan Athonitul, Intre iadul deznădejdii şi iadul smereniei, trad. Ioan I. Ică jr., Alba Iulia, Edit. Deisis, 1994. 